\title{
Interaction between the genetic risk score and dietary protein intake on cardiometabolic traits in Southeast Asian
}

\author{
Sooad Alsulami ${ }^{1,2}$, A. S. Aji ${ }^{3,4}$, U. Ariyasra ${ }^{3}$, S. R. Sari ${ }^{3}$, N. Tasrif ${ }^{5}$, F. F. Yani ${ }^{6}$, J. A. Lovegrove ${ }^{2,7}$, I. R. Sudji ${ }^{8}$,
} N. I. Lipoeto ${ }^{9}$ and K. S. Vimaleswaran ${ }^{2,7^{*}}$

\begin{abstract}
Background: Cardiometabolic diseases are complex traits which are influenced by several single nucleotide polymorphisms (SNPs). Thus, analysing the combined effects of multiple gene variants might provide a better understanding of disease risk than using a single gene variant approach. Furthermore, studies have found that the effect of SNPs on cardiometabolic traits can be influenced by lifestyle factors, highlighting the importance of analysing gene-lifestyle interactions.

Aims: In the present study, we investigated the association of 15 gene variants with cardiometabolic traits and examined whether these associations were modified by lifestyle factors such as dietary intake and physical activity.

Methods: The study included 110 Minangkabau women [aged 25-60 years and body mass index (BMI) $25.13 \pm 4.2 \mathrm{~kg} / \mathrm{m}^{2}$ ] from Padang, Indonesia. All participants underwent a physical examination followed by anthropometric, biochemical and dietary assessments and genetic tests. A genetic risk score (GRS) was developed based on 15 cardiometabolic diseaserelated SNPs. The effect of GRS on cardiometabolic traits was analysed using general linear models. GRS-lifestyle interactions on continuous outcomes were tested by including the interaction term (e.g. lifestyle factor ${ }^{*} G R S$ ) in the regression model. Models were adjusted for age, BMI and location (rural or urban), wherever appropriate.

Results: There was a significant association between GRS and BMl, where individuals carrying 6 or more risk alleles had higher BMl compared to those carrying 5 or less risk alleles $(P=0.018)$. Furthermore, there were significant interactions of GRS with protein intake on waist circumference $(W C)$ and triglyceride concentrations $\left(P_{\text {interaction }}=0.002\right.$ and 0.003, respectively). Among women who had a lower protein intake ( $13.51 \pm 1.18 \%$ of the total daily energy intake), carriers of six or more risk alleles had significantly lower WC and triglyceride concentrations compared with carriers of five or less risk alleles ( $P=0.0118$ and 0.002 , respectively).

Conclusions: Our study confirmed the association of GRS with higher BMI and further showed a significant effect of the GRS on WC and triglyceride levels through the influence of a low-protein diet. These findings suggest that following a lower protein diet, particularly in genetically predisposed individuals, might be an effective approach for addressing cardiometabolic diseases among Southeast Asian women.
\end{abstract}

Keywords: GRS, BMI, WC, Triglyceride, Interaction, Indonesian

\footnotetext{
* Correspondence: v.karani@reading.ac.uk

${ }^{2}$ Hugh Sinclair Unit of Human Nutrition, Department of Food and Nutritional

Sciences, University of Reading, PO Box 226, Whiteknights, Reading RG6 6AP,

UK

${ }^{7}$ Institute for Cardiovascular and Metabolic Research (ICMR), University of

Reading, Reading, UK

Full list of author information is available at the end of the article
}

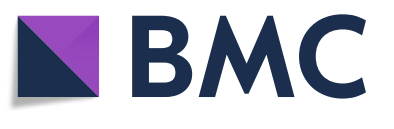

(c) The Author(s). 2020 Open Access This article is licensed under a Creative Commons Attribution 4.0 International License, which permits use, sharing, adaptation, distribution and reproduction in any medium or format, as long as you give appropriate credit to the original author(s) and the source, provide a link to the Creative Commons licence, and indicate if changes were made. The images or other third party material in this article are included in the article's Creative Commons licence, unless indicated otherwise in a credit line to the material. If material is not included in the article's Creative Commons licence and your intended use is not permitted by statutory regulation or exceeds the permitted use, you will need to obtain permission directly from the copyright holder. To view a copy of this licence, visit http://creativecommons.org/licenses/by/4.0/. 


\section{Introduction}

Cardiometabolic diseases such as cardiovascular diseases (CVD), obesity, hypertension and type 2 diabetes are a major cause of mortality, morbidity and healthcare spending worldwide $[1,2]$. The prevalence of these diseases has significantly increased and has become a major problem given the significant economic burden that these diseases impose on lowand middle-income countries. Indonesia has the seventh largest number of diabetic patients (7.6 million), despite relatively low prevalence worldwide (4.8\%) in 2012 [3]. In 2013, it was estimated that there were more than 132.8 million people with diabetes in the Western Pacific (more people than in any other region), and the number is expected to rise to 201.8 million by 2035 [4]. Furthermore, obesity is suggested to play a critical role in the development of chronic and non-communicable diseases (NCDs) in the Southeast (SE) Asia [5]. In Indonesia, NCDs are estimated to account for $73 \%$ of all deaths [6] of which, CVD contributed to $35 \%$ followed by cancers (12\%) and diabetes (6\%) [6].

Indonesia is the largest island country in the world, consisting of various ethnic groups distributed over 33 provinces [7]. Minangkabau community is the world's largest matrilineal society which resides mostly in West Sumatra, where the prevalence of low level of high-density lipoprotein cholesterol (HDL-C), hypertension and central obesity is more than 50\% [7]. It is reported that the Minangkabau ethnic group had a high risk of dyslipidemia, which is suggested to be driven mainly by the high intake of dietary fat from poor quality sources [8]. A study comparing lipid profiles among four ethnic groups reported that the Minangkabau ethnic group has the highest levels of plasma total cholesterol and lowdensity lipoprotein cholesterol (LDL-C) compared to other larger ethnicities including Sundanese, Javanese and Buginese [9]. Furthermore, it has been reported that the prevalence of central obesity is high among Minangkabau women [10]. Many environmental exposures contribute to the increasing prevalence of cardiometabolic diseases, but one key factor is urbanisation [11]. Countries in SE Asia have undergone rapid epidemiological and nutritional transitions over the past few decades. Furthermore, it has been reported that dietary risks, high blood pressure and tobacco smoking are the three major risk factors contributing to disease burden in Indonesia [12]. However, genetic factors also play an important role in the development of cardiometabolic diseases.

Candidate gene studies and genome-wide association studies (GWAS) have identified several single nucleotide polymorphisms (SNPs) relating to cardiometabolic diseases and traits in the Asian populations [13-16]. Most cardiometabolic traits are influenced by thousands of
SNPs each having a relatively small effect on the trait when present alone. Thus, analysing the combined effects of multiple gene variants might provide a better understanding of trait variability of an individual and improve risk prediction of cardiometabolic diseases than using a single variant approach [17]. Furthermore, studies have found that the effect of genetic variants on cardiometabolic traits can be influenced by lifestyle factors [18]. It has been confirmed that using genetic risk score (GRS) approaches increases the power to detect genelifestyle interactions compared to the common single variant methods [19]. Therefore, our study aimed to investigate the association of a novel GRS with cardiometabolic traits and to examine whether lifestyle factors such as dietary intake and physical activity modified these associations in 110 Minangkabau women.

\section{Methods \\ Study participants}

The study included healthy women who were enrolled in the Minangkabau Indonesia Study on Nutrition and Genetics (MINANG) study, a cross-sectional pilot study conducted in the city of Padang, West Sumatra, Indonesia, between December 2017 and January 2018. This study is a part of the ongoing GeNuIne (gene-nutrient interactions) Collaboration, which aims to examine the interactions between genetic and dietary factors (nutrigenetics) on cardiometabolic disease and its related traits using population-based studies from several ethnic groups [20]. The methodology of the study has been published elsewhere [21]. In brief, 133 women were recruited from community health centres in two subdistricts in Padang City including Padang Timur and Kuranji districts to represent both urban and rural areas of Padang population, respectively. The inclusion criteria included healthy women, aged 25-60 years old and with Minangkabau ethnicity. Of the 133 enrolled women, 10 were excluded from the study according to the following exclusion criteria: being pregnant or lactating $(N=0)$ and taking dietary or vitamin supplements $(N=0)$; have a previous history of hypertension, CVD or type 2 diabetes $(N$ =6); have a body mass index (BMI) of more than $40 \mathrm{~kg}$ / $\mathrm{m}^{2}$ or being classified as morbidly obese by a practitioner $(N=0)$; being blood related to other participants in the study $(N=0)$; have any communicable disease $(N=4)$. Of the remaining 123 participants, we excluded another 5 women who did not undergo blood sampling. Thus, the final sample consisted of 118 participants, of whom seven women did not have complete genetic information about all the investigated SNPs and were excluded from the GRS analysis $(N=111)$. Additionally, one participant with no dietary information available was excluded from the GRS interaction analysis $(N=110)$. 
The MINANG study was conducted according to the principles of the Declaration of Helsinki and was approved by the Ethical Review Committee of the Medical Faculty, Andalas Univesity (No.311/KEP/FK/2017). All participants gave their written informed consent before participating and had the right to withdraw from the study at will and opt-out from any of the procedures.

\section{Anthropometric measures}

Body weight (to the nearest $100 \mathrm{~g}$ ) and height (to the nearest $\mathrm{mm}$ ) were measured using an electronic scale (Seca 803, Seca GmbH. Co. kg, Hamburg, Germany) and a wallmounted stadiometer (OneMed Medicom stature meter, YF.05.05. V.A.1022, Indonesia), respectively. BMI was calculated as weight $(\mathrm{kg}) /$ height $(\mathrm{m})^{2}$ and categorised according to the Asia-Pacific classification of BMI [22]. Waist circumference (WC) was measured in centimetre using a metal tape (Medline-OneMed Medicom, Jakarta, Indonesia) midway between the 12th rib and the superior border of the iliac crest at the end of normal expiration.

\section{Biochemical and clinical measures}

After $12 \mathrm{~h}$ of fasting, blood samples $(5 \mathrm{ml})$ were taken to measure the concentrations of glucose, insulin, glycated haemoglobin A1c (HbA1c), total cholesterol, triglycerides, LDL-C and HDL-C. Samples were assayed using the xMark Microplate Spectrophotometer (Bio-Rad Laboratories Inc, Hercules, California, USA). Fasting glucose, insulin and HbA1c were measured using enzymelinked immunosorbent assay (ELISA) kits from Bioassay Technology Laboratory (Shanghai, China). Blood lipids were analysed using enzymatic colorimetric procedures, namely GPO-PAP for triglycerides and CHOD-PAP for total cholesterol, LDL and HDL. A sphygmomanometer was used to measure systolic and diastolic blood pressures (SBP and DBP). Measurements were taken twice at 5 -min intervals, and the average was recorded.

\section{Assessment of dietary intake and physical activity}

Information about dietary intake and physical activity was collected by a well-trained nutritionist in the home or in an integrated health service post. Diet was assessed using a previously validated and published semi-quantitative food frequency questionnaire (SQ-FFQ) consisting of a list of 223 food items [23]. Briefly, participants were asked to report the frequency of consumption (number of times per day, week or month) and portion size of various food items. Participants were provided with portion size images of all relevant foods to enhance reporting accuracy while completing the SQ-FFQ [24]. All collected data were double-checked for accuracy and analysed with the Indonesian Food Database and Nutrisurvey (EBISpro, Germany) to estimate total energy and macronutrient intake. Values of nutrient intake were adjusted for total energy intake using the nutrient (energy-adjusted) residual method, wherever appropriate [25].

"The Global Physical Activity Questionnaire" (GPAQ) was used to calculate an individual's level of physical activity in 3 areas (work, transport and leisure-time) and time spent in sedentary behaviour [26]. Total time spent in moderate-to-vigorous physical activity was estimated using to the World Health Organization (WHO) STEPwise method and was expressed as metabolic equivalent minutes per day (METmins/day). Participants were defined as "active" if they did $\geq 600 \mathrm{METmins/week} \mathrm{or} \mathrm{"in-}$ active" if they accumulated < 600 METmins/week.

\section{SNP selection and genotyping}

Fifteen genetic variants located at 8 different genes were selected for the present study based on its consistent associations with cardiometabolic traits in candidate gene studies and GWAS in Asian populations [13-16, 27-36]. The selected genetic variants were Calpain 10 (CAPN10) rs3792267 and rs5030952; fat mass and obesity-associated (FTO)- rs9939609, rs10163409 and rs8050136; melanocortin 4 Receptor $(M C 4 R)$ - rs17782313 and rs2229616; transcription factor 7-like 2 (TCF7L2)- rs12255372 and rs7903146; potassium voltage-gated channel subfamily Q member 1 (KCNQ1)- rs2237895 and rs2237892; cyclindependent kinase inhibitor 2A/2B (CDKN2A/2B)rs10811661; peroxisome proliferator-activated receptor gamma (PPARG)- rs1801282; and adiponectin (ADIPOQ)rs266729 and rs17846866.

Genomic DNA was extracted from peripheral blood leukocytes using the PureLink Genomic DNA Mini Kit (Invitrogen, Carlsbad, USA). Furthermore, a NanoDrop spectrophotometer was used to determine DNA concentration. The SNPs were genotyped using the competitive allele-specific PCR-KASP ${ }^{\bullet}$ assay at LGC Genomics (http://www.lgcgroup.com/services/ genotyping).

\section{Statistical analysis}

Statistical analysis was performed using the SPSS software (version 23). Common obesity was defined based on the Asia-Pacific classification of BMI for Asians, where non-obese individuals (BMI $<23 \mathrm{~kg} / \mathrm{m}^{2}$ ) and obese individuals (BMI $\geq 23 \mathrm{~kg} / \mathrm{m}^{2}$ ) were classed accordingly [37]. Central obesity was defined based on WHO classification of WC (WC $>80 \mathrm{~cm}$ for women) [38]. The Hardy-Weinberg equilibrium (HWE) was assessed using the $x^{2}$ goodness-of-fit test, and the 15 SNPs were in HWE $(P>0.05)$. Normality of distribution of all continuous variables was tested using the Shapiro-Wilk test and those that were not normally distributed were natural log-transformed before the analysis, including glucose, insulin, HbAC1, HDL-C, LDL-C, total cholesterol, triglyceride concentrations and total dietary protein 
intake (\%). Continuous variables are expressed as means and standard deviations (SD), and comparisons between groups were made using the independent $t$ test. The descriptive statistics for categorical variables, such as physical activity level, were obtained by determining frequency distributions and compared between individuals with and without central obesity using Pearson's chi-squared test. The association between individual SNPs and cardiometabolic traits was analysed using general linear models adjusted for age, residential area (rural or urban) and BMI when BMI is not an outcome. As the number of individuals with rare homozygous genotypes was low, a dominant model was used, where common homozygous genotypes were compared against combined rare homozygous and heterozygous genotypes.

A GRS was constructed based on 15 SNPs from 8 genes. An additive genetic model was assumed for each gene variant, assigning a score of 0,1 and 2 to genotypes containing 0,1 or 2 risk alleles, respectively. The GRS was then calculated for each individual by summing the number of risk alleles in the genetic variants. The count method assumed that each risk allele contributes equally and independently to the development of cardiometabolic traits. The average number of risk alleles per individual for the GRS was 5.12 (SD = 2.06), which ranged from 2 to 10. The GRS variable was then categorised into two groups based on the median of risk alleles: "low genetic risk group"-individuals with a GRS $\leq 5$ risk alleles $(N=69)$ and "high genetic risk group"-individuals with GRS $>5$ risk alleles $(N=42)$. The effects of GRS on cardiometabolic traits were analysed using general linear models. Furthermore, GRS-lifestyle interactions on continuous outcomes were tested using linear regression models by including the interaction terms (e.g. diet"genotype) in these models. Models were adjusted for age, residential area and additionally for BMI when it is not an outcome. Lifestyle factors that were investigated in our study included dietary intake and physical activity. Carbohydrate, protein and fat intakes were expressed as a percentage of total energy intake, and fibre intake was expressed in grammes. Furthermore, statistically significant interactions were investigated in more depth, where individuals were stratified by the tertiles of dietary intake and the levels of physical activity. A $P$ value of $<0.05$ was considered statistically significant. Multiple testing correction was not applied given that we had examined only one genetic instrument (i.e. GRS).

\section{Results}

Characteristics of the study participants according to the central obesity status

In the present study, 71 women (64.0\%) were centrally obese and 39 (35.1\%) were not. The characteristics of the participants are shown in Table 1 . In general, centrally obese participants were older and had higher SBP $(P=$ $0.006)$, fasting plasma glucose $(P=0.039)$, serum triglycerides $(P<0.001)$, serum total cholesterol $(P<0.001)$ and LDL-C $(P<0.001)$ concentrations compared to participants without central obesity. There were no significant differences in fasting HDL-C, serum insulin, HbA1c, DBP, dietary intake and physical activity levels and the distribution of GRS between the two groups $(P>0.05)$.

\section{Associations between GRS and cardiometabolic traits}

To explore the combined effect of the 15 SNPs on various cardiometabolic traits, a GRS was calculated. There was a significant association $(P=0.018)$ between the GRS and BMI where individuals carrying 6 or more risk alleles of the SNPs had higher BMI compared with those carrying 5 or less risk alleles (Table 2).

\section{Interactions between GRS and dietary intake on cardiometabolic traits}

There were significant interactions between the GRS and protein intake (\%) on WC and triglyceride concentrations $\left(P_{\text {interaction }}=0.002\right.$ and 0.003 , respectively) (Table 3$)$. With low protein intake $(13.51 \pm 1.18 \%)$, carriers of 6 or more risk alleles of SNPs had lower WC and triglyceride concentration compared to carriers of 5 or less risk alleles $(P$ $=0.0118$ and 0.002 , respectively) (Figs. 1 and 2). A significant interaction between protein intake and GRS was also detected on cholesterol levels $\left(P_{\text {interaction }}=0.021\right)$. Moreover, there were no other interactions between nutrient intake and GRS on cardio-metabolic traits.

\section{Associations between individual SNPs and cardiometabolic traits}

As shown in supplementary Table 1, Additional File 1, we found that the risk alleles of the three FTO SNPs rs9939609, rs8050136 and rs10163409 were associated with higher BMI $(P=0.006,0.007$ and 0.047 , respectively). Furthermore, SNPs rs12255372 (TCF7L2), rs2237892 (KCNQ1) and rs5030952 (CAPN10) were associated with increased fasting serum LDL-C concentrations $(P=0.032,0.039$ and 0.04 , respectively). A significant association was also found between the risk allele of the SNP rs17782313 (MC4R) and higher insulin level $(P=0.036)$. No significant association was observed between the remaining SNPs and cardiometabolic traits in this population $(P>0.05)$.

\section{Discussion}

The present study aimed to investigate the effects of genetic predisposition and lifestyle factors on cardiometabolic traits in Minangkabau women. In agreement with other studies [39], we have shown that the GRS based on 8 susceptible genes for cardiometabolic diseases is a significant risk factor for higher BMI in our study 
Table 1 Anthropometric and biochemical characteristics of the study participants

\begin{tabular}{|c|c|c|c|c|c|c|c|}
\hline & $N$ & Total $(N=111)$ & $N$ & $\begin{array}{l}\text { Non-centrally obese (WC } \leq 80 \mathrm{~cm})(N= \\
\text { 39) }\end{array}$ & $N$ & $\begin{array}{l}\text { Centrally obese }(\mathrm{WC}>80 \mathrm{~cm})(N= \\
\text { 71) }\end{array}$ & $\begin{array}{l}P \\
\text { value* }\end{array}$ \\
\hline Age (years) & 111 & $40.49 \pm 10.18$ & 39 & $37.08 \pm 11.68$ & 71 & $42.58 \pm 8.62$ & 0.012 \\
\hline BMI $\left(\mathrm{kg} / \mathrm{m}^{2}\right)$ & 111 & $25.13 \pm 4.2$ & 39 & $21.85 \pm 3.71$ & 71 & $26.99 \pm 3.24$ & $<0.001$ \\
\hline WC $(\mathrm{cm})$ & 110 & $83.85 \pm 10.27$ & 39 & $72.79 \pm 6.03$ & 71 & $89.92 \pm 6.26$ & $<0.001$ \\
\hline Glucose (mg/dl) & 111 & $92.53 \pm 20.67$ & 39 & $87.21 \pm 9.78$ & 71 & $95.69 \pm 24.29$ & 0.039 \\
\hline Insulin (mIU/L) & 111 & $\begin{array}{l}32,428.5 \pm 25 \\
706.13\end{array}$ & 39 & $31,073.79 \pm 28,460.35$ & 71 & $33,374.28 \pm 24,368.83$ & 0.657 \\
\hline $\mathrm{HbA1c}(\mathrm{ng} / \mathrm{ml})$ & 111 & $655.59 \pm 601.59$ & 39 & $629.22 \pm 671.07$ & 71 & $666.42 \pm 568.14$ & 0.759 \\
\hline Triglycerides (mg/dl) & 111 & $98.8 \pm 43.47$ & 39 & $78.26 \pm 34.19$ & 71 & $109.72 \pm 44.38$ & $<0.001$ \\
\hline Cholesterol (mg/dl) & 111 & $209.31 \pm 44.02$ & 39 & $188.26 \pm 30.04$ & 71 & $221.77 \pm 45.74$ & $<0.001$ \\
\hline HDL-C (mg/dl) & 111 & $59.12 \pm 10.29$ & 39 & $60.9 \pm 10.45$ & 71 & $58.14 \pm 10.22$ & 0.182 \\
\hline LDL-C (mg/dl) & 111 & $128.12 \pm 39.85$ & 39 & $111.49 \pm 25.55$ & 71 & $138.2 \pm 42.65$ & $<0.001$ \\
\hline SBP (mmHg) & 111 & $113.37 \pm 9.07$ & 39 & $110.14 \pm 8.83$ & 71 & $115.05 \pm 8.81$ & 0.006 \\
\hline $\mathrm{DBP}(\mathrm{mmHg})$ & 111 & $77.44 \pm 6.39$ & 39 & $76.26 \pm 8.35$ & 71 & $78.06 \pm 5.01$ & 0.223 \\
\hline $\begin{array}{l}\text { Total energy (kcal/ } \\
\text { day) }\end{array}$ & 110 & $1776.24 \pm 611.43$ & 39 & $1789.55 \pm 604.31$ & 70 & $1755.6 \pm 613.59$ & 0.781 \\
\hline $\begin{array}{l}\text { Carbohydrate intake } \\
(\%)\end{array}$ & 110 & $53.97 \pm 9.44$ & 39 & $52.67 \pm 7.86$ & 70 & $54.91 \pm 10.1$ & 0.235 \\
\hline Protein intake (\%) & 110 & $16.93 \pm 3.32$ & 39 & $17.13 \pm 2.93$ & 70 & $16.76 \pm 3.54$ & 0.579 \\
\hline Fat intake (\%) & 110 & $28.95 \pm 7.99$ & 39 & $30.05 \pm 6.87$ & 70 & $28.16 \pm 8.45$ & 0.235 \\
\hline Dietary fibre (g) & 110 & $8.78 \pm 4.29$ & 39 & $9.11 \pm 4.52$ & 70 & $8.56 \pm 4.19$ & 0.521 \\
\hline SFA (g) & 110 & $20.84 \pm 11.22$ & 39 & $21.77 \pm 10.81$ & 70 & $20.07 \pm 11.35$ & 0.447 \\
\hline MUFA (g) & 110 & $8.18 \pm 4.6$ & 39 & $9.00 \pm 5.08$ & 70 & $7.62 \pm 4.18$ & 0.129 \\
\hline PUFA (g) & 110 & $6.32 \pm 3.5$ & 39 & $6.67 \pm 3.06$ & 70 & $6.14 \pm 3.76$ & 0.541 \\
\hline MET (min/week) & 111 & $1311.89 \pm 1877.78$ & 39 & $1114.87 \pm 1625.95$ & 71 & $1428.45 \pm 2016.27$ & 0.407 \\
\hline GRS & 110 & $5.09 \pm 2.07$ & 39 & $4.77 \pm 2.01$ & 71 & $5.31 \pm 2.03$ & 0.189 \\
\hline \multirow[t]{3}{*}{ Physical activity levels } & 44 & $\begin{array}{l}\text { Sedentary } \\
(39.64 \%)\end{array}$ & 18 & Sedentary (46.15\%) & 26 & Sedentary (36.62\%) & 0.616 \\
\hline & 55 & $\begin{array}{l}\text { Moderate } \\
(49.55 \%)\end{array}$ & 17 & Moderate (43.59\%) & 37 & Moderate (52.11\%) & \\
\hline & 12 & Vigorous (10.81\%) & 4 & Vigorous (10.26\%) & 8 & Vigorous (11.27\%) & \\
\hline
\end{tabular}

Data presented as means \pm SD for continuous variables and as percentages for categorical variables

$B M I$ body mass index, WC waist circumference, $H b A 1 C$ glycated haemoglobin A1C, HDL-C high-density lipoprotein cholesterol, $L D L-C$ low-density lipoprotein cholesterol, SBP systolic blood pressure, DBP diastolic blood pressure, SFA saturated fatty acids, MUFA monounsaturated fatty acids, PUFA polyunsaturated fatty acids, MET metabolic equivalent of task, GRS genetic risk score

${ }^{*} P$ values for the differences in the means and proportions between non-centrally obese and centrally obese individuals were calculated using the independent $t$ test and the Chi-squared test, respectively

sample and might be a useful tool in characterising Minangkabau women at high risk for obesity. We found that women carrying 6 or more alleles had significantly higher BMI compared to those carrying 5 or less risk alleles. Furthermore, we found a significant interaction between the GRS and dietary protein intake (\%) on WC and triglyceride levels, where, among those who consumed a low protein diet (mean intake \pm SD $13.51 \pm$ $1.18 \%$ ), individuals, despite carrying more than 6 risk alleles, had significantly lower WC and triglyceride levels. Given that Minangkabau women have a high risk of dyslipidemia [9] and the prevalence of common and central obesity is high among this ethnic group [10], it is important to develop effective strategies targeting these conditions to improve public health.

It has been suggested that centrally obese participants defined as normal weight based on BMI had the worst long-term survival even when compared with their overweight and obese counterparts [40]. In addition, recent data from 42,702 European participants reported that central obesity is associated with higher mortality risk even in normal-weight individuals [41]. This is of concern for Asian populations, where increased levels of visceral adiposity are observed in those with normal BMIs [42-44]. Furthermore, the combination of increased WC along with elevated triglyceride levels has been 
Table 2 Associations between GRS and cardiometabolic traits

\begin{tabular}{|c|c|c|c|c|c|}
\hline & GR & & GRS & & $P$ value* \\
\hline & $N$ & Mean \pm SE & $\bar{N}$ & Mean \pm SE & \\
\hline BMI $\left(\mathrm{kg} / \mathrm{m}^{2}\right)$ & 69 & $24.52 \pm 0.52$ & 42 & $26.14 \pm 0.6$ & 0.018 \\
\hline WC (cm) & 68 & $84.28 \pm 1.22$ & 42 & $83.16 \pm 1.66$ & 0.334 \\
\hline Log glucose (mg/dl) & 69 & $93.65 \pm 2.98$ & 42 & $90.69 \pm 1.72$ & 0.327 \\
\hline Log insulin (m/U/L) & 69 & $32,365.29 \pm 3199.95$ & 42 & $32,532.33 \pm 3782.96$ & 0.196 \\
\hline Log HbA1C (ng/ml) & 69 & $650.58 \pm 71.1$ & 42 & $663.81 \pm 96.65$ & 0.527 \\
\hline Log triglycerides (mg/dl) & 69 & $101.07 \pm 5.27$ & 42 & $95.07 \pm 6.67$ & 0.142 \\
\hline Log cholesterol (mg/dl) & 69 & $212.88 \pm 5.59$ & 42 & $203.43 \pm 6.11$ & 0.228 \\
\hline Log HDL-C (mg/dl) & 69 & $58.55 \pm 1.26$ & 42 & $60.05 \pm 1.56$ & 0.404 \\
\hline Log LDL-C (mg/dl) & 69 & $131.84 \pm 4.97$ & 42 & $122 \pm 5.73$ & 0.197 \\
\hline $\log$ SBP $(\mathrm{mmHg})$ & 69 & $113.12 \pm 1.08$ & 42 & $113.77 \pm 1.43$ & 0.679 \\
\hline Log DBP (mmHg) & 69 & $77.59 \pm 0.86$ & 42 & $77.2 \pm 0.76$ & 0.535 \\
\hline
\end{tabular}

BMI body mass index, WC waist circumference, HbA1C glycated haemoglobin A1C, HDL-C high-density lipoprotein cholesterol, LDL-C low-density lipoprotein cholesterol, SBP systolic blood pressure, DBP diastolic blood pressure

* $P$ values obtained from linear regression analysis adjusted for age, residential area and additionally for BMI when BMI is not an outcome. The analysis was performed on log-transformed variables

previously defined as the 'hypertriacylglycerolaemic waist' phenotype [45]. Studies have shown that individuals with this phenotype have an increased risk of higher visceral adiposity, CVD, insulin resistance and other related outcomes [45]. Therefore, targeting this phenotype will have significant public health implications in terms of reducing NCD mortality in Asian populations.

In the present study, the average protein intake was 77 $\pm 37 \mathrm{~g} /$ day, which exceeded the recommended dietary protein daily allowance of $57-59 \mathrm{~g} /$ day for Indonesian women $[46,47]$. Observational studies have shown that higher protein intake was significantly associated with increases in body weight, BMI and fat mass [48-50]. These results are in contrast to the finding from intervention studies, which have shown that high protein intake enhances weight loss and provides a better longterm maintenance of reduced intra-abdominal fat stores $[37,51]$. These inconsistencies might be attributed to the sample size, genetic heterogeneity and gene-lifestyle interactions. Cross-sectional studies have demonstrated the association of several SNPs with obesity-related traits [52-55], and interaction of these SNPs with dietary intake of protein on weight change [56-58]. It has been shown that high protein diets can modulate the genetic effect of FTO variants on body weight, BMI and WC [59-61]. According to a 2-year weight loss intervention programme, carriers of the risk allele 'A' of the FTO SNP rs1558902 had a greater reduction in weight and

Table 3 Interactions between GRS and lifestyle factors on cardio-metabolic traits

\begin{tabular}{|c|c|c|c|c|c|}
\hline & Carbohydrate (\%) & Protein (\%) & Fat (\%) & Fibre (g) & Physical activity \\
\hline BMI $\left(\mathrm{kg} / \mathrm{m}^{2}\right)$ & 0.961 & 0.282 & 0.721 & 0.876 & 0.362 \\
\hline WC (cm) & 0.224 & 0.002 & 0.577 & 0.614 & 0.297 \\
\hline Log glucose (mg/dl) & 0.882 & 0.751 & 0.732 & 0.833 & 0.106 \\
\hline Log insulin (mIU/L) & 0.336 & 0.341 & 0.48 & 0.216 & 0.909 \\
\hline Log HbA1C (ng/ml) & 0.766 & 0.638 & 0.935 & 0.162 & 0.626 \\
\hline Log triglycerides (mg/dl) & 0.066 & 0.003 & 0.355 & 0.262 & 0.479 \\
\hline Log cholesterol (mg/dl) & 0.081 & 0.021 & 0.261 & 0.583 & 0.308 \\
\hline Log HDL-C (mg/dl) & 0.978 & 0.905 & 0.984 & 0.323 & 0.540 \\
\hline Log LDL-C (mg/dl) & 0.266 & 0.337 & 0.431 & 0.896 & 0.721 \\
\hline $\log$ SBP $(\mathrm{mmHg})$ & 0.156 & 0.291 & 0.208 & 0.872 & 0.644 \\
\hline Log DBP (mmHg) & 0.966 & 0.815 & 0.732 & 0.292 & 0.743 \\
\hline
\end{tabular}

Data are $P$ values obtained from linear regression analysis adjusted for age, residential area and BMI when BMI is not an outcome. The analysis was performed on log-transformed variables

$B M I$ body mass index, WC waist circumference, $H b A 1 C$ glycated haemoglobin A1C, HDL-C high-density lipoprotein cholesterol, $L D L-C$ low-density lipoprotein cholesterol, SBP systolic blood pressure, DBP diastolic blood pressure 


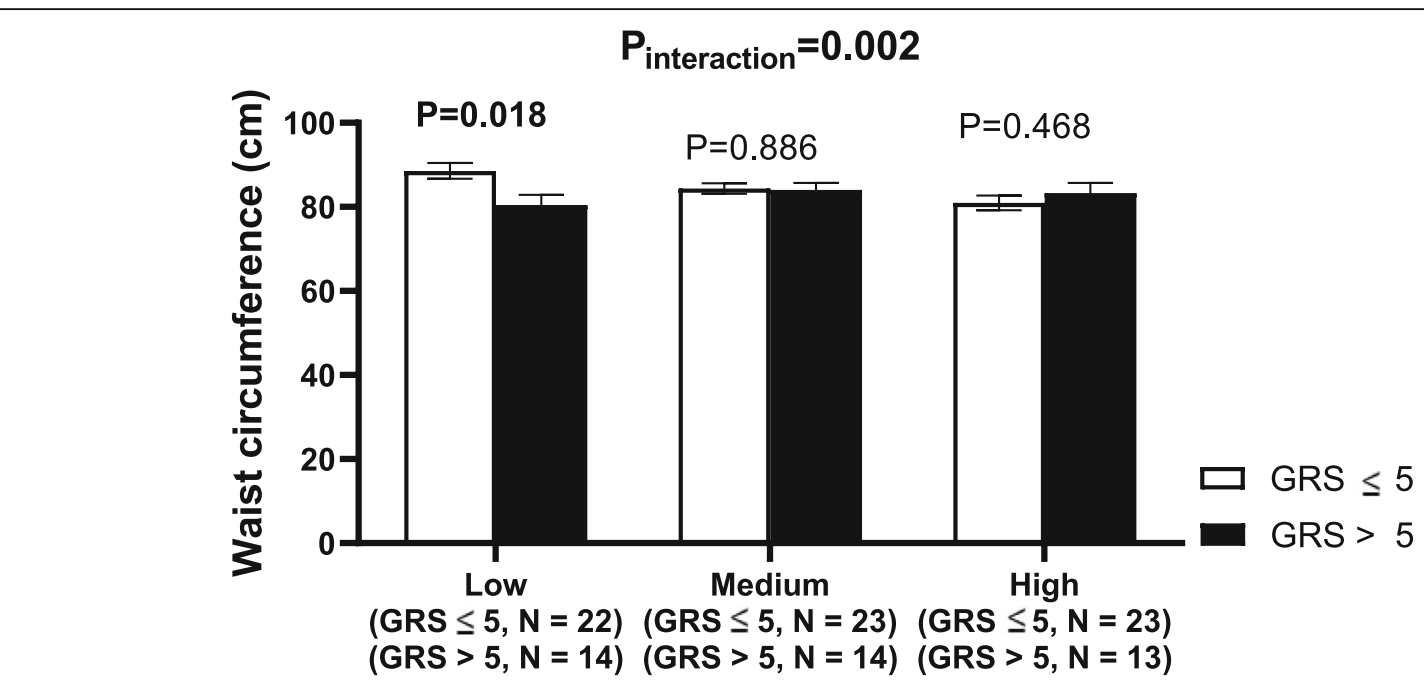

Tertiles of Protein Intake (\%)

Fig. 1 Interaction between genetic risk score (GRS) and log protein intake (\%) on waist circumference (WC). White bars indicate "low genetic risk group": individuals with a GRS $\leq 5$ risk alleles; black bars indicate "high genetic risk group": individuals with GRS > 5 risk alleles. Carriers of 6 or more risk alleles had lower WC compared to carriers of 5 or less risk alleles, among individual with lower protein intake (13.51 $\pm 1.18 \%)$

regional fat compared to non-carriers when high protein diets were consumed, whereas an opposite genetic effect was found on changes in fat distribution in response to a low-protein intake [60]. However, studies investigating the joint effect of genetic variants have reported conflicting results [62-64], indicating that the influence of genetic predisposition on changes in body weight and WC does not seem to be modulated by protein intake. In contrast, the present study provides evidence for GRSprotein intake interactions on WC and triglyceride concentrations, and these interactions were independent of potential confounding effects. We found that participants with 6 or more risk alleles who consumed a low protein diet (mean intake \pm SD $13.51 \pm 1.18 \%$ ) had significantly lower $\mathrm{WC}$ and triglyceride concentrations compared to those with 5 or less risk alleles. This

\section{$P_{\text {interaction }}=0.003$}

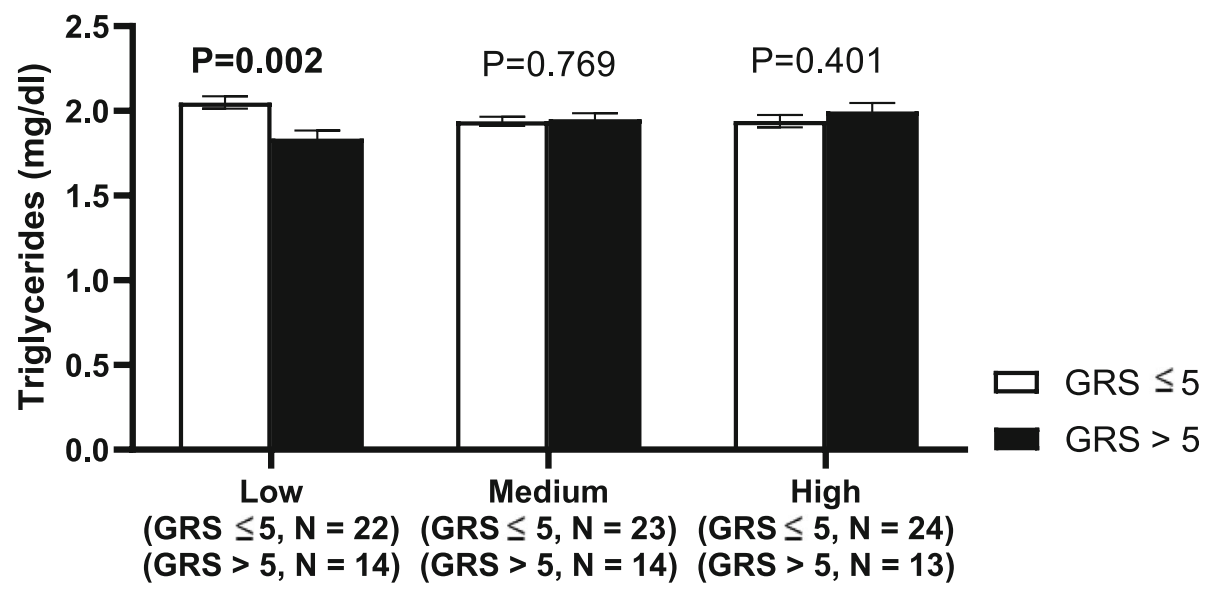

\section{Tertiles of Protein Intake (\%)}

Fig. 2 Interaction between genetic risk score (GRS) and log protein intake (\%) on log triglyceride levels. White bars indicate "low genetic risk group": individuals with a GRS $\leq 5$ risk alleles; black bars indicate "high genetic risk group": individuals with GRS > 5 risk alleles. Carriers of 6 or more risk alleles had lower triglyceride level compared to carriers of 5 or less risk alleles, among individual with lower protein intake (13.51 $\pm 1.18 \%$ ) 
difference in the findings across the studies might be due to differences in the sample size, methods used to construct GRSs (weighted vs. unweighted) and the number of SNPs included in the GRSs.

The observed interaction between GRS and dietary protein on WC and triglyceride concentrations might be driven by the source of protein consumed, which has not been analysed in our study. Different protein sources have different effects on body weight and fat mass, and the mechanisms behind this are still very speculative and need more investigation. The higher intake of protein from animal sources (protein from red and processed meat and poultry) was found to be associated with an increase in body weight in both genders, with a stronger association in women [49]. Diet rich in animal protein might reflect the western pattern diet characterised by high red meat consumption, which has shown to be associated with weight gain [65]. In contrast, a study has shown that protein from meat is associated with lower weight gain because it produces a higher 24-h energy expenditure compared to soy protein [66]. This hypothesis is, however, based on a mechanistic study, and it is still unknown whether this applies in the long run to individuals of the free-living populations. Furthermore, it has been suggested that consuming protein from dairy sources may prevent weight gain and promote abdominal fat loss [67]. Here, the suggested mechanism primarily relates to the high content of calcium, which may function synergistically in combination with bioactive compounds, such as angiotensin-converting enzyme inhibitors and the rich concentration of branched-chain amino acids [67]. While the above-mentioned studies failed to explore the genetic aspects, our study did not investigate the type of protein that was consumed by the participants; hence, future studies examining the effect of both factors are required.

In agreement with some studies [62,63], no interactions were detected between GRS and dietary intake of protein, fat and carbohydrate on BMI in the present study. However, a study in the European population ( $N=48,170$ adults) has shown that the joint effect of 93 obesity-related SNPs on BMI might be modulated by the intake of total energy, fat and saturated fat [64]. Furthermore, studies have shown that an obesogenic diet and physical inactivity with relatively high intake of sugar-sweetened beverages and prolonged television watching might exaggerate the effect of genetic factors on adiposity $[18,68]$. Even though several studies have demonstrated that physical activity could attenuate the combined genetic influence of multiple SNPs on BMI and obesity risk $[18,69,70]$, no such interactions were detected in the present study.
The strengths of our study include the use of a well-defined population, a validated SQ-FFQ [23] and a genetic risk score generated from the 15 genetic variants associated with cardiometabolic traits. Also, the main exposures investigated in our study were collected by well-trained staff and using validated and standardised operating procedures. However, there are limitations that need to be acknowledged. Although our analysis was adjusted for several factors, the potential for confounding by unmeasured or unknown factors exist. Even though our study has a small sample size, we were still able to find significant associations and interactions suggesting that our study is well powered. Even though food intake was assessed using validated methods, recall bias and measurement errors in these selfreported FFQs cannot be fully eliminated, which could alter the true underlying interactions between dietary and genetic factors on cardiometabolic traits [71, 72]. Finally, our study was restricted to Minangkabau women, and it is unknown whether our findings could be generalised to men or other demographic or ethnic groups.

\section{Conclusion}

In the present study, we have shown a significant effect of the GRS on WC and triglyceride levels through the influence of a low protein intake, where individuals with a high genetic susceptibility can overcome the risk of higher WC and triglyceride levels by consuming a low protein diet. These findings are potentially relevant for public health; however, future trials in both genders with larger sample size and objective measures of protein intake, such as urinary nitrogen, are needed to confirm these findings.

\section{Supplementary information}

Supplementary information accompanies this paper at https://doi.org/10. 1186/s12263-020-00678-w.

Additional file 1:. Supplementary Table 1 Associations between individual SNPS and cardiometabolic traits.

\section{Acknowledgements \\ We thank all study participants for their cooperation. Dr Karani S \\ Vimaleswaran acknowledges support from the Ministry of Higher Education} of Saudi Arabia for the scholarship given to Ms. Sooad Alsulami.

\section{Authors' contributions}

SA and ASA performed the statistical analyses and data interpretation; SA and KSV drafted the manuscript; KSV and ASA carried out data collection; KSV designed the nutrigenetics study; NIL, FFY and KSV conceived, supervised and designed the study; UA and SRS contributed to data collection, monitoring and evaluation of participants, and project administration; NT was involved in data collection and dietary data analysis IRS conducted the laboratory analysis; NIL and JAL critically reviewed the manuscript. All authors read and approved the final manuscript. 


\section{Funding}

This research was funded by the British Council Newton Fund Researcher Links Travel Grant: 2016-RLTG7-10215.

\section{Availability of data and materials}

The datasets used and/or analysed during the current study are available from the corresponding author on reasonable request.

\section{Ethics approval and consent to participate}

The MINANG study was conducted according to the principles of the Declaration of Helsinki and was approved by the Ethical Review Committee of the Medical Faculty, Andalas Univesity (No.311/KEP/FK/2017). All participants gave their written informed consent before participating.

\section{Consent for publication}

The consent for publication has been obtained from all the participants.

\section{Competing interests}

The authors declare that they have no competing interests.

\section{Author details}

${ }^{1}$ Department of Clinical Nutrition, Faculty of Applied Medical Sciences, King Abdulaziz University, Jeddah, Saudi Arabia. ${ }^{2}$ Hugh Sinclair Unit of Human Nutrition, Department of Food and Nutritional Sciences, University of Reading, PO Box 226, Whiteknights, Reading RG6 6AP, UK. ${ }^{3}$ Postgraduate Department of Biomedical Science, Faculty of Medicine, Andalas University, Padang, West Sumatra, Indonesia. ${ }^{4}$ Department of Nutrition, Faculty of Health Science, Universitas Alma Ata, Yogyakarta, Indonesia. ${ }^{5}$ Public Health Department, Faculty of Medicine, Andalas University, Padang, Indonesia. ${ }^{6}$ Department of Child Health, Faculty of Medicine, Andalas University, Padang, Indonesia. ${ }^{7}$ Institute for Cardiovascular and Metabolic Research (ICMR), University of Reading, Reading, UK. ${ }^{8}$ Biomedical Laboratory, Faculty of Medicine, Andalas University, Padang, Indonesia. 'Department of Nutrition, Faculty of Medicine, Andalas University, Padang, Indonesia.

Received: 5 December 2019 Accepted: 30 September 2020

Published online: 12 October 2020

\section{References}

1. Leal J, Luengo-Fernandez R, Gray A, Petersen S, Rayner M. Economic burden of cardiovascular diseases in the enlarged European Union. Eur Heart J. 2006;27(13):1610-9.

2. World Health Organization: Cardiovascular diseases (CVDs) (2015). www. who.int/mediacentre/factsheets/fs317/en/index.html. Accessed 31 May 2019.

3. Soewondo P, Ferrario A, Tahapary DL. Challenges in diabetes management in Indonesia: a literature review. Glob Health. 2013;9:63.

4. International Diabetes Federation: IDF diabetes atlas. 6th ed. (2013). https:// diabetesatlas.org/. Accessed 31 May 2019.

5. Dans A, Ng N, Varghese C, Tai ES, Firestone R, Bonita R. The rise of chronic non-communicable diseases in Southeast Asia: time for action. Lancet (London, England). 2011;377(9766):680-9.

6. World Health Organization: Indonesia - noncommunicable diseases country profile (2010). http://www.who.int/nmh/countries/idn_en.pdf. Accessed 31 May 2019.

7. Herningtyas EH, Ng TS. Prevalence and distribution of metabolic syndrome and its components among provinces and ethnic groups in Indonesia. BMC Public Health. 2019;19(1):377.

8. Ratna Djuwita P, Sudijanto Kamso,. Nutrients intake pattern of a Minangkabau ethnic group. MAKARA, KESEHATAN,. 2003;7(1).

9. Hatma RD. Lipid profiles among diverse ethnic groups in Indonesia. Acta Med Indones. 2011:43(1):4-11.

10. Desmawati DS, Yuniar Lestari, Ulya Uti Fasrini, Afriwardi. Fat intake is associated with nutritional status in Minangkabau adult women: a crosssectional study. PakJNutr. 2019;18:387-90.

11. Angkurawaranon C, Jiraporncharoen W, Chenthanakij B, Doyle P, Nitsch D. Urban environments and obesity in Southeast Asia: a systematic review, meta-analysis and meta-regression. PLoS One. 2014;9(11):e113547.

12. Mboi N, Murty Surbakti I, Trihandini I, Elyazar I, Houston Smith K, Bahjuri Ali $P$, et al. On the road to universal health care in Indonesia, 1990-2016: a systematic analysis for the global burden of disease study 2016. Lancet (London, England). 2018;392(10147):581-91.
13. Cho YS, Chen CH, Hu C, Long J, Ong RT, Sim X, et al. Meta-analysis of genome-wide association studies identifies eight new loci for type 2 diabetes in east Asians. Nat Genet. 2011;44(1):67-72.

14. Kim YJ, Go MJ, Hu C, Hong CB, Kim YK, Lee JY, et al. Large-scale genomewide association studies in east Asians identify new genetic loci influencing metabolic traits. Nat Genet. 2011:43(10):990-5.

15. Unoki H, Takahashi A, Kawaguchi T, Hara K, Horikoshi M, Andersen G, et al. SNPs in KCNQ1 are associated with susceptibility to type 2 diabetes in east Asian and European populations. Nat Genet. 2008;40(9):1098-102.

16. Wu Y, Gao H, Li H, Tabara Y, Nakatochi M, Chiu YF, et al. A meta-analysis of genome-wide association studies for adiponectin levels in east Asians identifies a novel locus near WDR11-FGFR2. Hum Mol Genet. 2014;23(4):1108-19.

17. Dudbridge F. Polygenic epidemiology. Genet Epidemiol. 2016;40(4):268-72.

18. Qi Q, Qi L. Sugar-sweetened beverages, genetic risk, and obesity. N Engl J Med. 2013:368(3):286-7.

19. Huls A, Kramer U, Carlsten C, Schikowski T, Ickstadt K, Schwender H. Comparison of weighting approaches for genetic risk scores in geneenvironment interaction studies. BMC Genet. 2017;18(1):115.

20. Vimaleswaran KS. Gene-nutrient interactions on metabolic diseases: findings from the GeNulne collaboration. Nutr Bull. 2017;42(1):80-6.

21. Surendran S, Aii AS, Ariyasra U, Sari SR, Malik SG, Tasrif N, et al. A nutrigenetic approach for investigating the relationship between vitamin B12 status and metabolic traits in Indonesian women. J Diabetes Metab Disord. 2019:1-11.

22. Pan WH, Yeh WT. How to define obesity? Evidence-based multiple action points for public awareness, screening, and treatment: an extension of Asian-Pacific recommendations. Asia Pac J Clin Nutr. 2008;17(3):370-4.

23. Lipoeto NI, Agus Z, Oenzil F, Wahlqvist M, Wattanapenpaiboon N. Dietary intake and the risk of coronary heart disease among the coconutconsuming Minangkabau in West Sumatra, Indonesia. Asia Pac J Clin Nutr. 2004;13(4):377-84

24. Kemenkes R. Buku Foto Makanan Survei Konsumsi Makanan Individu (SKMI2014). Hipokrate: Jakarta; 2016.

25. Willett WC, Howe GR, Kushi LH. Adjustment for total energy intake in epidemiologic studies. Am J Clin Nutr. 1997;65(4 Suppl):1220S-8S discussion 9S-31S.

26. Armstrong T, Bull F. Development of the World Health Organization global physical activity questionnaire (GPAQ). J Public Health. 2006;14(2):66-70.

27. Apalasamy YD, Ming MF, Rampal S, Bulgiba A, Mohamed Z. Association of melanocortin-4 receptor gene polymorphisms with obesity-related parameters in Malaysian Malays. Ann Hum Biol. 2013;40(1):102-6.

28. Chang YC, Liu PH, Yu YH, Kuo SS, Chang TJ, Jiang YD, et al. Validation of type 2 diabetes risk variants identified by genome-wide association studies in Han Chinese population: a replication study and meta-analysis. PLoS One. 2014;9(4):e95045.

29. Croteau-Chonka DC, Marvelle AF, Lange EM, Lee NR, Adair LS, Lange LA, et al. Genome-wide association study of anthropometric traits and evidence of interactions with age and study year in Filipino women. Obesity (Silver Spring, Md). 2011, 19(5):1019-27.

30. Illangasekera YA, Kumarasiri RP, Fernando DJ, Dalton CF. Association of FTO and near MC4R variants with obesity measures in urban and rural dwelling Sri Lankans. Obes Res Clin Pract. 2016:10(Suppl 1):S117-s24.

31. Ji MJ, Ku EJ, Oh TK, Jeon HJ. Association of adiponectin $45 \mathrm{~T} / \mathrm{G}$ polymorphism with diabetic cardiovascular complications in Korean type 2 diabetes. J Korean Med Sci. 2018;33(17):e124.

32. Kaur H, Badaruddoza B, Bains V, Kaur A. Genetic association of ADIPOQ gene variants $(-3971 A>G$ and $+276 G>T)$ with obesity and metabolic syndrome in north Indian Punjabi population. PLoS One. 2018;13(9):e0204502.

33. Kommoju UJ, Maruda J, Kadarkarai Samy S, Irgam K, Kotla JP, Reddy BM. Association of IRS1, CAPN10, and PPARG gene polymorphisms with type 2 diabetes mellitus in the high-risk population of Hyderabad, India. Journal of Diabetes. 2014;6(6):564-73.

34. Lee YH, Kang ES, Kim SH, Han SJ, Kim CH, Kim HJ, et al. Association between polymorphisms in SLC30A8, HHEX, CDKN2A/B, IGF2BP2, FTO, WFS1, CDKAL1, KCNQ1 and type 2 diabetes in the Korean population. J Hum Genet. 2008;53(11-12):991-8.

35. Ramya K, Radha V, Ghosh S, Majumder PP, Mohan V. Genetic variations in the FTO gene are associated with type 2 diabetes and obesity in south Indians (CURES-79). Diabetes Technol Ther. 2011;13(1):33-42.

36. Vasan SK, Fall T, Neville MJ, Antonisamy B, Fall CH, Geethanjali FS, et al. Associations of variants in FTO and near MC4R with obesity traits in south Asian Indians. Obesity (Silver Spring, Md). 2012;20(11):2268-77.

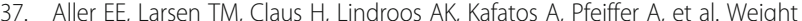
loss maintenance in overweight subjects on ad libitum diets with high or 
low protein content and glycemic index: the DIOGENES trial 12-month results. International Journal of Obesity (2005). 2014;38(12):1511-7.

38. World Health Organization: Waist circumference and waist-hip ratio report of a WHO expert consultation (2011). https://www.who.int/nutrition/ publications/obesity/WHO_report_waistcircumference_and_waisthip_ratio/ en/. Accessed 22 April 2019.

39. Vimaleswaran KS, Loos RJ. Progress in the genetics of common obesity and type 2 diabetes. Expert Rev Mol Med. 2010;12:e7.

40. Sahakyan KR, Somers VK, Rodriguez-Escudero JP, Hodge DO, Carter RE, Sochor $\mathrm{O}$, et al. Normal-weight central obesity: implications for total and cardiovascular mortality. Ann Intern Med. 2015;163(11):827-35.

41. Hamer M, O'Donovan G, Stensel D, Stamatakis E. Normal-weight central obesity and risk for mortality. Ann Intern Med. 2017;166(12):917-8.

42. Deurenberg-Yap M, Chew SK, Deurenberg P. Elevated body fat percentage and cardiovascular risks at low body mass index levels among Singaporean Chinese, Malays and Indians. Obesity Rev. 2002;3(3):209-15.

43. McKeigue PM, Shah B, Marmot MG. Relation of central obesity and insulin resistance with high diabetes prevalence and cardiovascular risk in south Asians. Lancet (London, England). 1991;337(8738):382-6.

44. Wang J, Thornton JC, Russell M, Burastero S, Heymsfield S, Pierson RN Jr. Asians have lower body mass index (BMI) but higher percent body fat than do whites: comparisons of anthropometric measurements. Am J Clin Nutr. 1994;60(1):23-8.

45. Tanko LB, Bagger YZ, Qin G, Alexandersen P, Larsen PJ, Christiansen C. Enlarged waist combined with elevated triglycerides is a strong predictor of accelerated atherogenesis and related cardiovascular mortality in postmenopausal women. Circulation. 2005;111(15):1883-90.

46. Nutritional adequacy rate (AKG) (2013). https://bohmks.blogspot.com/2014/ 01/angka-kecukupan-gizi-akg-2013.html. Accessed 13 Nov 2019.

47. WFP/FAO: Modeling the future of Indonesian food consumption (2018), https://www.wfp.org/publications/wfpfao-modeling-future-indonesian-foodconsumption-june-2018. Accessed 13 Nov 2019.

48. Ankarfeldt MZ, Gottliebsen K, Angquist L, Astrup A, Heitmann BL, Sorensen TI. Dietary protein and urinary nitrogen in relation to 6-year changes in fat mass and fat-free mass. International journal of obesity (2005). 2015;39(1):162-8.

49. Halkjaer J, Olsen A, Overvad K, Jakobsen MU, Boeing H, Buijsse B, et al. Intake of total, animal and plant protein and subsequent changes in weight or waist circumference in European men and women: the Diogenes project. International journal of obesity (2005). 2011;35(8):1104-13.

50. Vergnaud AC, Norat T, Mouw T, Romaguera D, May AM, Bueno-de-Mesquita HB, et al. Macronutrient composition of the diet and prospective weight change in participants of the EPIC-PANACEA study. PLoS One. 2013;8(3):e57300.

51. Due A, Toubro S, Skov AR, Astrup A. Effect of normal-fat diets, either medium or high in protein, on body weight in overweight subjects: a randomised 1-year trial. Int J Obes Relat Metab Disord. 2004;28(10):1283-90.

52. Heid IM, Jackson AU, Randall JC, Winkler TW, Qi L, Steinthorsdottir V, et al. Meta-analysis identifies 13 new loci associated with waist-hip ratio and reveals sexual dimorphism in the genetic basis of fat distribution. Nat Genet. 2010;42(11):949-60.

53. Loos RJ, Lindgren CM, Li S, Wheeler E, Zhao JH, Prokopenko I, et al. Common variants near MC4R are associated with fat mass, weight and risk of obesity. Nat Genet. 2008;40(6):768-75.

54. Scuteri A, Sanna S, Chen WM, Uda M, Albai G, Strait J, et al. Genome-wide association scan shows genetic variants in the FTO gene are associated with obesity-related traits. PLoS Genet. 2007:3(7):e115.

55. Thorleifsson G, Walters GB, Gudbjartsson DF, Steinthorsdottir V, Sulem P, Helgadottir $A$, et al. Genome-wide association yields new sequence variants at seven loci that associate with measures of obesity. Nat Genet. 2009;41(1):18-24.

56. Fisher E, Meidtner K, Angquist L, Holst C, Hansen RD, Halkjaer J, et al. Influence of dietary protein intake and glycemic index on the association between TCF7L2 HapA and weight gain. Am J Clin Nutr. 2012;95(6):1468-76.

57. Larsen LH, Angquist L, Vimaleswaran KS, Hager J, Viguerie N, Loos RJ, et al. Analyses of single nucleotide polymorphisms in selected nutrient-sensitive genes in weight-regain prevention: the DIOGENES study. Am J Clin Nutr. 2012;95(5):1254-60.

58. Stocks T, Angquist L, Hager J, Charon C, Holst C, Martinez JA, et al. TFAP2B -dietary protein and glycemic index interactions and weight maintenance after weight loss in the DiOGenes trial. Hum Hered. 2013;75(2-4):213-9.

59. de Luis DA, Aller R, Izaola O, Primo D, Urdiales S, Romero E. Effects of a high-protein/low-carbohydrate diet versus a standard hypocaloric diet on weight and cardiovascular risk factors: role of a genetic variation in the rs9939609 FTO gene variant. J Nutrigenet Nutrigenomics. 2015;8(3):128-36.

60. Zhang X, Qi Q, Zhang C, Smith SR, Hu FB, Sacks FM, et al. FTO genotype and 2-year change in body composition and fat distribution in response to weight-loss diets: the POUNDS LOST trial. Diabetes. 2012;61(11):3005-11.

61. Merritt DC, Jamnik J, El-Sohemy A. FTO genotype, dietary protein intake, and body weight in a multiethnic population of young adults: a crosssectional study. Genes Nutr. 2018;13:4.

62. Ankarfeldt MZ, Larsen SC, Angquist L, Husemoen LL, Roswall N, Overvad K et al. Interaction between genetic predisposition to adiposity and dietary protein in relation to subsequent change in body weight and waist circumference. PLoS One. 2014;9(10):e110890.

63. Rukh G, Sonestedt E, Melander O, Hedblad B, Wirfalt E, Ericson U, et al. Genetic susceptibility to obesity and diet intakes: association and interaction analyses in the Malmo diet and cancer study. Genes Nutr. 2013;8(6):535-47.

64. Celis-Morales CA, Lyall DM, Gray SR, Steell L, Anderson J, lliodromiti S, et al. Dietary fat and total energy intake modifies the association of genetic profile risk score on obesity: evidence from 48170 UK Biobank participants. International journal of obesity (2005). 2017;41(12):1761-8.

65. Schulze MB, Fung TT, Manson JE, Willett WC, Hu FB. Dietary patterns and changes in body weight in women. Obesity (Silver Spring, Md). 2006;14(8):1444-53.

66. Mikkelsen PB, Toubro S, Astrup A. Effect of fat-reduced diets on 24-h energy expenditure: comparisons between animal protein, vegetable protein, and carbohydrate. Am J Clin Nutr. 2000;72(5):1135-41.

67. Zemel MB. The role of dairy foods in weight management. J Am Coll Nutr. 2005;24(6 Suppl):537 s-46 s.

68. Li S, Zhao JH, Luan J, Ekelund U, Luben RN, Khaw KT, et al. Physical activity attenuates the genetic predisposition to obesity in 20,000 men and women from EPIC-Norfolk prospective population study. PLoS medicine. 2010;7(8).

69. Kilpelainen TP, Qi L, Brage S, Sharp SJ, Sonestedt E, Demerath E, et al. Physical activity attenuates the influence of FTO variants on obesity risk: a meta-analysis of 218,166 adults and 19,268 children. PLoS Med. 2011;8(11):e1001116.

70. Qi Q, Li Y, Chomistek AK, Kang JH, Curhan GC, Pasquale LR, et al. Television watching, leisure time physical activity, and the genetic predisposition in relation to body mass index in women and men. Circulation. 2012;126(15):1821-7.

71. Rimm EB, Giovannucci EL, Stampfer MJ, Colditz GA, Litin LB, Willett WC. Reproducibility and validity of an expanded self-administered semiquantitative food frequency questionnaire among male health professionals. Am J Epidemiol. 1992;135(10):1114-26 discussion 27-36.

72. Willett WC, Sampson L, Stampfer MJ, Rosner B, Bain C, Witschi J, et al. Reproducibility and validity of a semiquantitative food frequency questionnaire. Am J Epidemiol. 1985;122(1):51-65.

\section{Publisher's Note}

Springer Nature remains neutral with regard to jurisdictional claims in published maps and institutional affiliations.

\section{Ready to submit your research? Choose BMC and benefit from:}

- fast, convenient online submission

- thorough peer review by experienced researchers in your field

- rapid publication on acceptance

- support for research data, including large and complex data types

- gold Open Access which fosters wider collaboration and increased citations

- maximum visibility for your research: over $100 \mathrm{M}$ website views per year

At BMC, research is always in progress.

Learn more biomedcentral.com/submission 